\title{
A feasibility study of a cognitive behavioral based stress management intervention for nursing students: results, challenges, and implications for research and practice
}

\author{
Ulrik Terp ${ }^{*^{*}}$ D, Birgitta Bisholt ${ }^{2}$ and Fredrik Hjärthag ${ }^{1}$
}

\begin{abstract}
Background: Stress related psychological problems are growing in nursing education and constitute an essential challenge for educators. This makes research about strategies and interventions to meet these problems important. Stress management interventions need to be tested for feasibility and acceptability, before conducting large scale RCTs. The objective of our study was to assess the feasibility and acceptability of a newly developed cognitive behavioral stress management intervention for nursing students.

Methods: Data were collected using a combination of standardized measurements and newly created questionnaires in combination with qualitative data. Our data included recruitment capability, sample characteristics, intervention acceptability and preliminary evaluation of participant psychological changes.

Results: Findings suggested that the feasibility of conducting a full-scale evaluation was confirmed for intervention acceptability, data collection procedures, and adherence. However, difficulties relating to recruitment capability and homework were identified. All aspects taken together, the intervention was found feasible and acceptable to nursing students, and thus a potential stress management intervention for the nurse education context.

Conclusions: Overall, this study provides an insight into the challenges and complexities of developing and evaluating a new brief cognitive behavioral based stress management training intervention in a nurse education setting.
\end{abstract}

Keywords: Feasibility, Cognitive behavioral stress management, Nursing education, Stress, Health promotion

\section{Background}

Stress-related symptoms and psychological problems increase among nursing students during their education $[1,2]$. The stress has its starting points primarily in the academic and clinical context, together with stressors related to social and financial issues [3]. Unhealthy stress has dire consequences and correlates with learning

\footnotetext{
* Correspondence: ulrik.terp@kau.se

'Department of Social and Psychological Studies, Karlstad University, Universitetsgatan 2, 65188 Karlstad, Sweden

Full list of author information is available at the end of the article
}

difficulties, surface-oriented learning strategies, lack of motivation, relational problems, and thus negatively influences professional development and constitutes a significant challenge for nursing students to complete their education [2, 4-8]. There is also a link between stress and more severe mental health problems as anxiety and depression [9]. In addition, stress related problems are not restricted to the nursing education. Globally, there is a shortage of nurses, and there are problems related to stress within nurses work situations, and many leave their occupation [10]. Consequently, to provide students 
and employees with stress management skills is a key challenge for educators and future workplaces, which makes research to meet these problems important [11].

Systematic reviews have shown that stress management interventions based on a solid theoretical basis and training new behaviors have the most positive results [12-14]. Based on these principles, we developed a new cognitive behavioral therapy (CBT) - based stress management intervention for nursing students. The theoretical basis of this intervention is a mix of classical and modern CBT, which both shares the goal of helping individuals to develop adaptive behaviors [15].

\section{Study rationale and objectives}

When planning for a full-scale RCT of an intervention, it is essential to evaluate feasibility, acceptability, and data collection procedures as a preparation [16].

This study is the third and last part of a larger study focusing on these aspects of a newly developed stress management intervention. In our first study, using quantitative analyses, preliminary effects of the intervention were examined for stress management competency, selfefficacy and self-esteem (self-reference 1). In our second study, using a qualitative analysis, participants' perspectives of the intervention were described (self-reference 2 ). The goal of the present study is to identify further aspects of the intervention itself as well as elements of the implementation that need consideration and possible modifications, to answer the question "Can it work?", the central question of feasibility studies [17]. According to Orsmond and Cohn [14], there are five overarching objectives of feasibility studies focusing on social and behavioral interventions in particular. These are the assessment of recruitment capability and resulting sample characteristics, intervention acceptability, procedures and measures, a preliminary evaluation of participant responses, and resources and the ability to manage the study. Three of these are related to the aim of this study and described in Table 1.
Thus, the objective of this study was to investigate the feasibility of a newly developed cognitive-behavioral based stress management intervention for nursing students.

\section{Method}

\section{Settings and recruitment}

The study population consisted of Swedish nursing students in a three-year program (180 ECTS credits) at a medium-sized university, leading to both a professional and a Bachelor's degree. In Sweden, nursing programs follow the directions of the government regulations regarding the length of the education and learning objectives $[18,19]$. However, the university is free to decide the organization of the education and the order of courses. The clinical practice in the program accounted for approximately half of time and credits.

For this study participants were recruited by information meetings about the study, where background, aims, contents and ethical considerations were described and distributed, both orally and in writing. Interested students signed an informed consent, and were invited to join the planned intervention outside their ordinary schedule.

\section{Design and participants}

At each semester over 2 years, about 400 student nurses were invited to participate in this study at their second semester. Stress during nursing education in Sweden increases mainly between semester two and four [20], similar findings are shown for other countries [21]. Thus, we found recruitment of participants from the second semester most relevant. Since recruitment capability and intervention acceptability were in focus for this study, it was important not only to follow students taking full part of the intervention, but also to follow students who chose not to participate or who dropped out from the intervention after they had started their

Table 1 Study objectives as described by domains, main questions, data and outcomes

\begin{tabular}{|c|c|c|c|}
\hline \multicolumn{4}{|c|}{ Overarching question - Can it work? } \\
\hline Domain & Main questions & Data & $\begin{array}{l}\text { Study } \\
\text { outcome }\end{array}$ \\
\hline Recruitment capability & $\begin{array}{l}\text { Can we recruit appropriate participants? } \\
\text { What are the obstacles to recruitment? }\end{array}$ & $\begin{array}{l}\text { 1) Characteristics of the participants, } \\
\text { drop-outs and control group } \\
\text { 2) Recruitment obstacles and } \\
\text { dropout rates }\end{array}$ & Primary \\
\hline Intervention acceptability & $\begin{array}{l}\text { Is the intervention suitable for and acceptable to participants? } \\
\text { What are the adherence rates to the intervention? } \\
\text { What are the challenges related to adherence? }\end{array}$ & $\begin{array}{l}\text { 1) CSQ-8 } \\
\text { 2) Attendance rates } \\
\text { 3) Adherence rates }\end{array}$ & Primary \\
\hline $\begin{array}{l}\text { Outcome measures and } \\
\text { preliminary evaluation }\end{array}$ & $\begin{array}{l}\text { Does the intervention show promise of being successful with the } \\
\text { intended population? } \\
\text { Do participants provide qualitative feedback that may be indicative of } \\
\text { the likelihood that the intervention will be successful? }\end{array}$ & $\begin{array}{l}\text { 1) Standardized instruments } \\
\text { 2) Open-ended question }\end{array}$ & Secondary \\
\hline
\end{tabular}


participation. All these groups, forming the base for this study are presented in a flow diagram (Fig. 1).

Both external dropouts - operationalized as nonparticipating nursing students called 'Non participants questionnaire group' in Fig. 1 and internal dropouts operationalized as nursing students who participated less than five times, and/or did not fill out the post intervention assessment, called 'Participants - Drop outs' were studied. For preliminary evaluations, a pre-, post- and one-year follow up were conducted for the intervention group. Also, an independent control group was recruited from one fourth semester of nursing students, who had not had the opportunity to take part of the intervention, for the one-year follow up comparisons. The participants taking part of the intervention followed the same syllabus as the control group.

\section{The intervention - a cognitive behavioral stress management training program}

The first author developed the intervention built on both traditional and modern cognitive behavioral theories (Table 2) emphasizing the theoretical commonalities in goals, principles, and processes [15].

The overarching aim with the intervention is to promote psychological health. Not primarily by reducing stress, but through increasing psychological flexibility. Psychological flexibility is defined as "contacting the present moment as a conscious human being, fully and without needless defense - as it is and not as it says it is - and persisting with or changing a behavior in the service of chosen values" [22]. The ability of psychological flexibility was trained with the help of relevant theory and applied exercises. Research has shown this ability to be a central aspect of mental health [23].

Further, the intervention aimed at increasing the participants' awareness and theoretical knowledge about the interaction between cognitions, emotions, behavior, bodily reactions and contextual factors [24, 25]. Other aims with the stress management intervention were to identify and transfer useful and trainable alternative attitudes, thoughts, emotions, and behaviors to stressrelated contexts relevant to each of the participants individually. During the intervention, there was a strong emphasis on the importance of training new ways of coping with each participant's difficulties in everyday life, thus integrating and transferring new knowledge to previously challenging situations. To achieve these goals, theory-based mini-lectures, reflective group practices, exercises, and discussions were provided ten times in two-hour sessions over a ten to 12 week period of time.

\section{Primary outcomes \\ Recruitment capability}

Examining aspects of the recruitment process and the sample characteristics are essential in determining whether the intervention is perceived relevant to the study population [26]. These data are also important when evaluating the recruitment plan and thus in determining whether the stress management training intervention and future efficacy studies would be successful. Recruitment obstacles were assessed using a survey developed by the research team, including questions about motives for not participating in the intervention and in terms of perceived barriers and obstacles. Two different

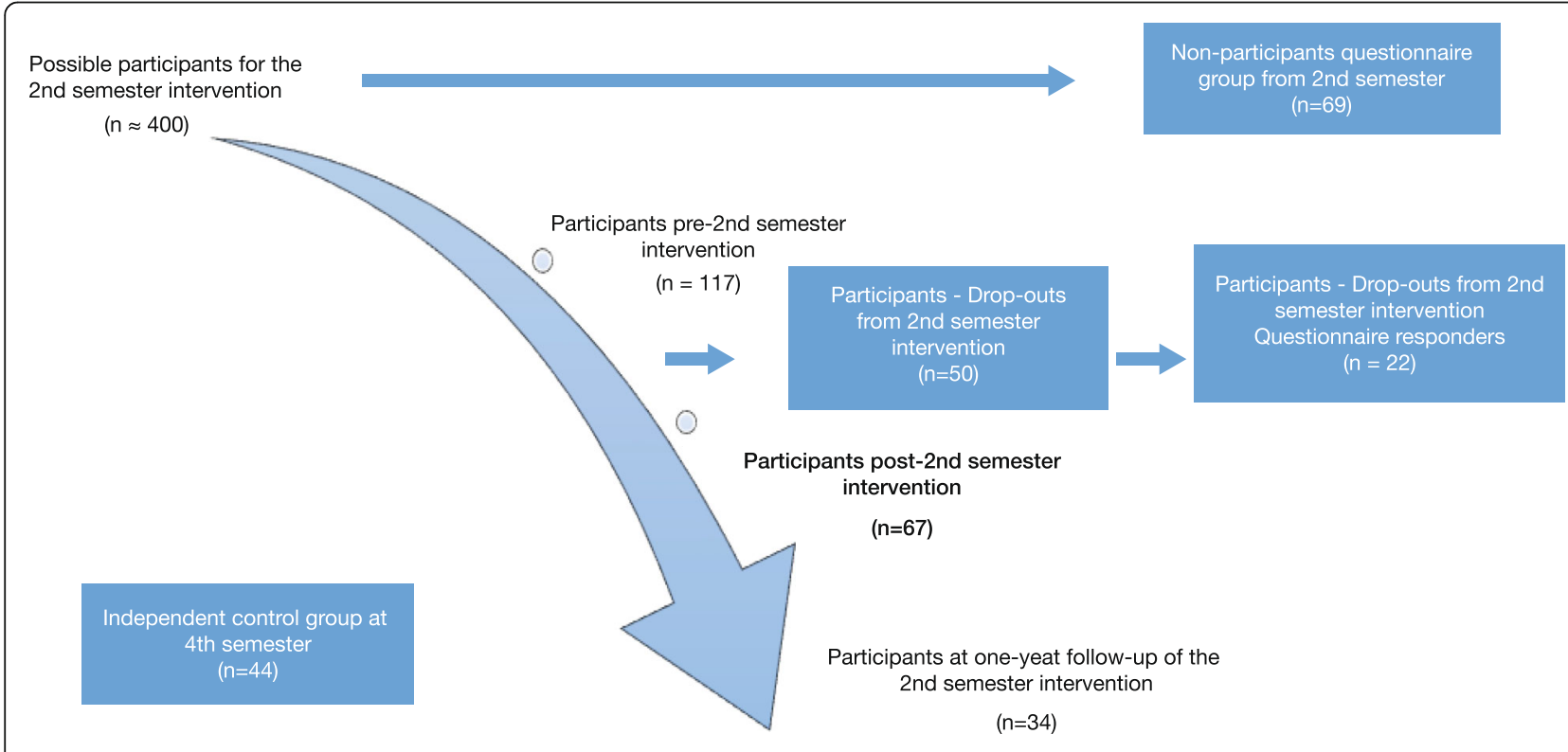

Fig. 1 Flow diagram over study participants 
Table 2 Brief description of the intervention; goals, principles, and processes presented together with the theoretical and practical foundations of the intervention

\begin{tabular}{|c|c|c|c|c|c|}
\hline Session & Main theoretical focus & Main exercise & $\begin{array}{l}\text { Main } \\
\text { change } \\
\text { principle }\end{array}$ & $\begin{array}{l}\text { Main } \\
\text { therapeutic } \\
\text { process }\end{array}$ & Main reference (s) \\
\hline 1. Introduction & $\begin{array}{l}\text { A brief description of the stress concept and } \\
\text { basic principles of CBT and the intervention as } \\
\text { a whole }\end{array}$ & The Five-factor model & - & - & $\begin{array}{l}\text { O'Donohue and Fisher } \\
\text { [24], Kuyken, Padesky } \\
\text { [25] }\end{array}$ \\
\hline $\begin{array}{l}\text { 2. Emotions } \\
\text { school }\end{array}$ & $\begin{array}{l}\text { What are emotions? } \\
\text { Why do we have emotions? }\end{array}$ & $\begin{array}{l}\text { Identify the function of } \\
\text { emotions }\end{array}$ & $\begin{array}{l}\text { Attention } \\
\text { change }\end{array}$ & $\begin{array}{l}\text { Attention } \\
\text { training }\end{array}$ & Passer and Smith [26] \\
\hline $\begin{array}{l}\text { 3. Emotions } \\
\text { school }\end{array}$ & Concept of acceptance and coping & $\begin{array}{l}\text { What do we need to } \\
\text { accept? } \\
\text { What would be different if } \\
\text { you come to peace with } \\
\text { it? }\end{array}$ & $\begin{array}{l}\text { Attention } \\
\text { change }\end{array}$ & $\begin{array}{l}\text { Acceptance/ } \\
\text { tolerance }\end{array}$ & Kåver [27] \\
\hline $\begin{array}{l}\text { 4. The importance } \\
\text { of thoughts }\end{array}$ & $\begin{array}{l}\text { The transaction model } \\
\text { Cognitive Traps } \\
\text { Vulnerability vs. resilience }\end{array}$ & Decision balance & $\begin{array}{l}\text { Cognitive } \\
\text { change }\end{array}$ & $\begin{array}{l}\text { Cognitive } \\
\text { reframing }\end{array}$ & Almén $[28,29]$ \\
\hline $\begin{array}{l}\text { 5. The importance } \\
\text { of thoughts }\end{array}$ & Procrastination & Worksheet with examples & $\begin{array}{l}\text { Cognitive } \\
\text { change }\end{array}$ & $\begin{array}{l}\text { Cognitive } \\
\text { reframing } \\
\text { Defusion }\end{array}$ & $\begin{array}{l}\text { Rozental and } \\
\text { Wennersten [30] }\end{array}$ \\
\hline 6. Self-compassion & What does self-compassion mean? & $\begin{array}{l}\text { Create a compassionate } \\
\text { self }\end{array}$ & $\begin{array}{l}\text { Cognitive } \\
\text { change }\end{array}$ & $\begin{array}{l}\text { Cognitive } \\
\text { reframing }\end{array}$ & Neff [31] \\
\hline $\begin{array}{l}\text { 7. Acceptance and } \\
\text { commitment } \\
\text { therapy }\end{array}$ & $\begin{array}{l}\text { The problem solving vs. it shows the } \\
\text { consciousness of interpretations of different } \\
\text { life themes } \\
\text { Psychological flexibility }\end{array}$ & The compass of life & $\begin{array}{l}\text { Context } \\
\text { engagement } \\
\text { Cognitive } \\
\text { change }\end{array}$ & $\begin{array}{l}\text { Behavioral } \\
\text { exposure } \\
\text { Defusion }\end{array}$ & Hayes, Strosahl [32] \\
\hline 8. Life's balances & $\begin{array}{l}\text { Review of important balances: } \\
\text { Requirements vs. control / influence } \\
\text { Activation vs. deactivation } \\
\text { Effort vs. reward }\end{array}$ & $\begin{array}{l}\text { Mapping your own } \\
\text { situation ldentifying } \\
\text { barriers to change }\end{array}$ & $\begin{array}{l}\text { Context } \\
\text { engagement }\end{array}$ & $\begin{array}{l}\text { Behavioral } \\
\text { activation }\end{array}$ & Bakker, Killmer [33] \\
\hline $\begin{array}{l}\text { 9. Effective } \\
\text { communication }\end{array}$ & Communication behaviors & $\begin{array}{l}\text { Identifying barriers to } \\
\text { effective communication }\end{array}$ & $\begin{array}{l}\text { Context } \\
\text { engagement }\end{array}$ & $\begin{array}{l}\text { Behavioral } \\
\text { exposure } \\
\text { Behavioral } \\
\text { activation }\end{array}$ & Almén [28] \\
\hline
\end{tabular}

versions of the dropout survey were used to identify obstacles and barriers for participation. An eight-item version for the non-participants and an extended 14-item version for the dropout group. The response alternatives ranged from $1=$ do not agree at all, to $4=$ totally agree see supplemental file. This gave information relevant to the recruitment issues for each specific group.

\section{Intervention acceptability}

Intervention acceptability is operationalized by how the individual participant in the intervention perceive the intervention [27]. The Client Satisfaction Questionnaire (CSQ-8) was used to assess participants, overall satisfaction with the quality of the intervention [28]. The questions of the questionnaire were, for example: To what extent has our program met your needs, and Have the services you received helped you to deal more effectively with your problems? with four response alternatives from poor to excellent on a Likert scale. The scale is frequently used for these purposes and shows good reliability and validity [29]. For cut-off points, levels presented by Lally, Byrne [30] were used. Further, in the follow-up measurement, the participants answered questions about their adherence to the intervention protocol, and their attendance was assessed in each session which was used and operationalized as an additional measure of intervention acceptability. The aim was to identify factors affecting implementation ease or difficulties. These data help to answer questions about the study procedures and whether the intervention is suitable, acceptable, and appealing to participants, thus questions of importance before conducting an RCT.

\section{Secondary outcomes \\ Quantitative preliminary evaluation}

The measures were based on a literature review and the documented psychometric properties reported in prior research with nursing students or a comparable population (Table 3).

Given the vast number of scales used in health research, it is important to assess if they appear to be sensitive to the effects of the intervention or if new or 
Table 3 Description of the instruments used in the present study

\begin{tabular}{|c|c|c|c|c|c|}
\hline Instrument & $\begin{array}{l}\text { Response } \\
\text { scale }\end{array}$ & $\begin{array}{l}\text { Number of } \\
\text { subscales }\end{array}$ & $\begin{array}{l}\text { Number of } \\
\text { items }\end{array}$ & Original reference & $\begin{array}{l}\text { Psychometric } \\
\text { properties }\end{array}$ \\
\hline Perceived Stress Scale (PSS) & 5-point Likert & - & 14 & Cohen, Kamarck [41] & Lee [42] \\
\hline Satisfaction with life scale (SWLS) & 7-point Likert & - & 5 & $\begin{array}{l}\text { Diener, Emmons } \\
\text { [43] }\end{array}$ & Pavot and Diener [44] \\
\hline Brief Cope Scale (BCS) & 4-point Likert & 14 & 28 & Carver [45] & Wong and Heriot [46] \\
\hline Pure Procrastination Scale (PPS) & 5-point Likert & - & 12 & Steel [47] & Rozental, Forsell [48] \\
\hline $\begin{array}{l}\text { The Hospital Anxiety and depression } \\
\text { scale (HADS) }\end{array}$ & 4-point Likert & 2 & 14 & $\begin{array}{l}\text { Zigmond and } \\
\text { Snaith [49] }\end{array}$ & Lisspers, Nygren [50] \\
\hline $\begin{array}{l}\text { Connor Davidson Resilience Scale } \\
\text { (CD-RISC-S) }\end{array}$ & 5-point Likert & - & 25 & $\begin{array}{l}\text { Connor and } \\
\text { Davidson [51] }\end{array}$ & Ahern, Kiehl [52] \\
\hline
\end{tabular}

modified measurements are required for the intended population [17].

Descriptive data are presented in Tables 7 and 8, with comparisons of means used t-tests or one-way ANOVAs when applicable. All analyses used significance level 5\% and were conducted using the IBM/SPSS software version 25.

\section{Open-ended survey data}

In the 1 year follow-up, an open-ended question was used in addition to the quantitative measurements, Can you describe any changes during your last year that you attribute to the intervention to investigate the participants' perceptions about whether the intervention affected them. Open-ended questions (OEQs) make it possible to collect data that cannot be captured through fixed response formats [31].

From the 73 participants who followed the intervention five sessions or more, 33 participants answered the open-ended question, which was analyzed using the six phases of thematic analysis [32]. The open-ended question generated 88 statements from participants who answered the question. The qualitative analysis process was carried out with NVivo version 12, which helped the first author to manage the coding process and enable the dependability of findings. In the next step, the codes were sorted into potential themes by the first and the second author separately. After that, XX and YY read and discussed each theme with associated codes repeatedly until consensus on the theme structure was reached, and no fundamental disagreements emerged during this process. Then themes were labelled. Finally, all three authors discussed and reached consensus about the interpretation of the findings.

\section{Ethical approval}

The study was carried out following the ethical guidelines of the latest Helsinki declaration and was approved by the Regional Ethical Board in Uppsala, Sweden (Approval number: 2014/379).

\section{Results}

Recruitment capability

Each semester, approximately 100 students begin their education in the nursing program. During 2015-2016, all were offered to participate in the intervention. This means that approximately 400 individuals were offered to attend over the four semesters the intervention was conducted. Totally 117 students chose to participate in the intervention, and approximately 280 chose not to participate. This gave a general average participation rate of about $29 \%$ for the current intervention.

\section{Sample characteristics}

First and most important for feasibility, is to answer the question 'Can we recruit the appropriate participants? and to investigate the obstacles to recruitment. Characteristics of the sample that followed the intervention, dropouts, and the control group are provided below (Table 4).

The group who followed the intervention (five sessions or more) and the dropout group did not differ in any background variables measured. This shows that there are no systematic differences between those who participated in the intervention and those who chose to withdraw from participation.

However, when comparing the intervention and the control group, our data shows a difference between how much time the student spent per week on studies and vocational work. The relationship between the number of hours the students spent on average each week on studies or work looks different from semester four. In their second semester, students on average placed more time on studies in relation to work, and this relationship did not apply to the control group. Whether this is a finding relevant outside our study sample is an open question, but according to studies, this is a phenomenon 
Table 4 Background characteristics for intervention participants, drop-outs and for the control group

\begin{tabular}{|c|c|c|c|}
\hline Background variables & $\begin{array}{l}\text { Intervention group } \\
(n=67)\end{array}$ & Drop-outs $(n=50)$ & $\begin{array}{l}\text { Control group } \\
(n=44)\end{array}$ \\
\hline Sex (male/female) & $7 / 60$ & $6 / 44$ & $3 / 41$ \\
\hline Age M (SD) & $26,31(6,91)$ & $26,32(7,38)$ & $24,70(3,43)$ \\
\hline \multicolumn{4}{|l|}{ Social situation } \\
\hline Married/civil partnership with children & 21 & 11 & 8 \\
\hline Married/civil partnership without children & 19 & 18 & 18 \\
\hline Living apart with children & 1 & - & - \\
\hline Living apart without children & 5 & 3 & 3 \\
\hline Single with children & - & - & 1 \\
\hline Single without children & 12 & 13 & 13 \\
\hline Living at home with parents or other with children & 9 & 5 & 1 \\
\hline \multicolumn{4}{|l|}{ Parents highest education } \\
\hline \multicolumn{4}{|l|}{ Mother } \\
\hline No education & 1 & 1 & 3 \\
\hline Elementary school & 8 & 9 & 5 \\
\hline Upper secondary education & 26 & 20 & 20 \\
\hline Academic education & 30 & 20 & 16 \\
\hline \multicolumn{4}{|l|}{ Father } \\
\hline No education & 2 & - & 5 \\
\hline Elementary education & 14 & 13 & 6 \\
\hline Upper secondary education & 33 & 27 & 24 \\
\hline Academic education & 18 & 9 & 8 \\
\hline About how many hours a week do you spend on your studies M (SD) & $34,36(7,51)$ & $31,85(9,09)$ & $25,65(9,37)^{* * *}$ \\
\hline Do you work outside your studies (Y/N) & $34 / 33$ & $23 / 27$ & $31 / 12^{*}$ \\
\hline Yes, about how many hours M (SD) & $8,94(4,25)$ & $10,91(5,53)$ & $13,03(5,79)^{* *}$ \\
\hline
\end{tabular}

*The difference between the intervention group and the control group is significant according to a Chi-2 test, $p<.05$

**The difference between the intervention group and the control group is significant according to an independent $\mathrm{t}$-test, $p<.01$

***The difference between the intervention group and the control group is significant according to an independent t-test, $p<.001$

relatively new to nurse education where the underlying assumption about the student is that he or she is a full or part-time student. This is an assumption with relevance for stress research [33].

In summary, our analysis of between-group differences revealed no selection bias considering sex, age, social background or educational level of the participants' parents or in time spent on studying and working when comparing the intervention group with the intervention dropout group; thus our sample is representative of the target study population, nursing students.

\section{Obstacles and dropout rates}

The reasons for non-participation and for intervention dropout were examined by a survey developed by the research team (see questions in Table 5). On two occasions, the questionnaire was distributed in connection with regular teaching in a full class. Individuals present at the time of this questionnaire distribution, who participated in the intervention between one to five occasions, but who chose not to complete it, voluntarily filled out this questionnaire. Answers from this group and answers given by nursing students offered to participate in the intervention but who chose not to do so, are shown in Table 5.

The table shows that the most common and most prominent reason for not completing the intervention was being busy with other tasks related to regular studies. In addition to this, time for leisure and extra work were also mentioned, but to a lesser extent as reasons for not completing the intervention. Correspondingly, those who chose not to participate in the intervention stated mainly that studies and leisure interests were the reasons for this. In addition to the fixed response options contained in the questionnaire, it was also possible to add comments to a final open question. The results of the open-ended questions showed that those who answered $(n=26)$ the question primarily mentioned long travel distances from their homes to the university as the main reason for choosing not to participate in the intervention, when there were no other scheduled activities. 
Table 5 Obstacles for participation in the intervention for the non-participants and dropout group. High scores indicate a high level of agreement with statements

\begin{tabular}{|c|c|c|c|c|}
\hline & $\begin{array}{l}\text { Group } \\
\text { Non-participants } \\
(n=69)\end{array}$ & & $\begin{array}{l}\text { Group } \\
\text { Dropouts } \\
(n=22)\end{array}$ & \\
\hline & $\begin{array}{l}\% \text { total agreement } \\
\text { with statement }^{\mathrm{a}}\end{array}$ & $\begin{array}{l}\% \text { totally disagree or partly } \\
\text { disagree with statement }{ }^{\mathrm{b}}\end{array}$ & $\begin{array}{l}\% \text { total agreement } \\
\text { with statement }^{\mathrm{a}}\end{array}$ & $\begin{array}{l}\% \text { totally disagree or partly } \\
\text { disagree with statement }{ }^{\mathrm{b}}\end{array}$ \\
\hline Not interested in stress management & 1 & 91 & 0 & 96 \\
\hline I do not have time because I work extra & 7 & 73 & 0 & 61 \\
\hline Hobbies & 12 & 42 & 9 & 74 \\
\hline Other tasks related to my studies & 31 & 41 & 36 & 18 \\
\hline My family situation & 3 & 91 & 9 & 74 \\
\hline $\begin{array}{l}\text { The program contains home } \\
\text { assignments }\end{array}$ & 3 & 77 & 0 & 87 \\
\hline $\begin{array}{l}\text { I don't want to share things about } \\
\text { myself with others }\end{array}$ & 1 & 97 & 4 & 78 \\
\hline $\begin{array}{l}\text { The program did not feel relevant when } \\
\text { it was presented to me }\end{array}$ & 11 & 79 & 0 & 91 \\
\hline $\begin{array}{l}\text { Course leader's ability to convey } \\
\text { knowledge }\end{array}$ & & & 0 & 96 \\
\hline $\begin{array}{l}\text { The relationship between the course } \\
\text { leader and I the student }\end{array}$ & & & 4 & 74 \\
\hline $\begin{array}{l}\text { That I did not do the home assignments } \\
\text { for the stress management program }\end{array}$ & & & 0 & 96 \\
\hline $\begin{array}{l}\text { The relationship between me and the } \\
\text { other students }\end{array}$ & & & 0 & 100 \\
\hline $\begin{array}{l}\text { My ability to absorb the information } \\
\text { from the lectures }\end{array}$ & & & 0 & 74 \\
\hline My ability to do the home assignments & & & 0 & 91 \\
\hline
\end{tabular}

a) Item score $4=$ total agreement with the statement

b) Item score 1 or 2 = totally disagree or partly disagree with the statement

\section{Intervention acceptability}

CSQ-8

The participants' satisfaction with the intervention was generally high. Most participants $(81.7 \%)$ had a total score between 27 and 32 points indicating that they were very satisfied with the intervention. $18.3 \%$ scored between 21 and 26 points indicating that they were satisfied. No participants had a total score below 23 points.

The result of CSQ-8 shows that overall, the participants were satisfied with the intervention. Most of the respondents were very satisfied and would highly recommend the intervention to others. The item that received the lowest rating was about how much the intervention responded to the participants' needs. In summary the participants expressed an overall high acceptability of the intervention.

\section{Attendance rates}

About half of the participants who attended the first intervention session, attended the tenth session. No specific occasions differ but overall the number of participants decreased regularly. The last group that participated, however, had a higher attendance throughout all sessions on average (Table 6).

Through all the groups, there were a total of 43 participants who participated in nine or ten sessions and in total 73 participated on five occasions or more, however data from 6 of these participants were lacking at the post-intervention assessments, thus only 67 of them

Table 6 Attendance distributed over the full intervention

\begin{tabular}{lllll}
\hline $\begin{array}{l}\text { Session } \\
\text { number }\end{array}$ & $\begin{array}{l}\text { Group 1 } \\
\text { Autumn }\end{array}$ & $\begin{array}{l}\text { Group 2 } \\
\text { Spring }\end{array}$ & $\begin{array}{l}\text { Group 3 } \\
\text { Autumn 2015 }\end{array}$ & $\begin{array}{l}\text { Group 4 } \\
\text { Spring 2016 }\end{array}$ \\
\hline 1 & 42 & 33 & 16 & 16 \\
2 & 38 & 29 & 12 & 12 \\
3 & 31 & 26 & 11 & 12 \\
4 & 33 & 25 & 10 & 13 \\
5 & 28 & 20 & 9 & 12 \\
6 & 27 & 25 & 5 & 11 \\
7 & 20 & 20 & 5 & 10 \\
8 & 22 & 21 & 7 & 10 \\
9 & 24 & 20 & 5 & 12 \\
10 & 21 & 16 & 7 & 13 \\
\hline
\end{tabular}


were considered full intervention completers in this study.

\section{Adherence}

At time for the post-intervention measurement, a question was asked about how the participants worked on the home assignments between each session. This measurement can be considered as one aspect of engagement with the intervention. We found that the participants did not adhere to the homework assigned each session as initially expected. From our data, it appears that a clear majority, 53 out of 73 participants, did not regularly work with the home assignments. Only six people stated that they regularly worked with home assignments.

\section{Outcome measures and preliminary evaluation Standardized instruments}

For all scales, except the pure procrastination scale as well as the perceived stress scale, there are significant differences between the pre- and post-intervention measures. For HAD-anxiety and CD-RISC, the improved results were also seen in the one-year followup. Regarding the Brief cope scale, it was only the sub-scales of self-distraction, self-blame as well as planning, where an improvement occurred between the first and the second measurement occasions. Regarding self-distraction and self-blame, the improved results were also seen at the one-year follow-up. The results indicate that the intervention influenced the participants positively regarding central mental health parameters (Tables 7 and 8).

In addition, analyses were made between the intervention group's one-year follow ups (now in their fourth semester) and the fourth semester control group measurements. Independent t-tests showed that there was a difference for HAD-anxiety $[t \quad(68.85)=2.07$; $p<.05]$, where the values were higher in the control group 7.95 (3.79) compared to the intervention group 6.53 (2.16). For PSS the values were also significantly [ $t$
$(58)=2.41 ; p<.05]$ higher in the control group 24.02 (7.99) compared to the intervention group 18.71 (6.93). For COPE-active coping, the intervention group showed a significantly $[t(76)=2.42 ; p<.05]$ higher value 6.74 (0.99) compared to the control group 6.16 (1.08). Otherwise, no other differences could be observed between the intervention group's one-year follow up and the control group.

\section{Open-ended survey data}

The thematic analysis revealed three themes; 'Focusing on self and relating deeper to others', 'Changed life perspective', and 'To know-how'.

\section{Focusing on the self and relating deeper to others}

In the first theme, the focus is on one's self and is primarily about self-knowledge and self-awareness. The participants described how, as a result of the intervention, they started to problematize and ask questions to themselves about demands they place on themselves and an increased acceptance of their personality.

"It has taught me to listen to myself, even taken help to rethink / correct in situations where I could influence. I have even gained a greater understanding and knowledge of my feelings." (Participant 2)

Through a combination of newly acquired psychological knowledge and reflective ability, several participants described how they have been positively influenced and gained greater self-knowledge.

\section{Changed life perspective}

The participants described that they have learned to handle stress in a different way, which has contributed to them looking at life in a new way and with a changed life perspective. For instance, it could be a change in perspective, as to whether a challenging life situation should be a problem or not.

Table 7 Comparisons between assessments M1-M3 of HAD, CD-RISC, SWLS, PPS and PSS

\begin{tabular}{|c|c|c|c|c|c|c|}
\hline & $\begin{array}{l}M 1 \\
M(S D)\end{array}$ & $\begin{array}{l}\text { M2 } \\
M(S D)\end{array}$ & $\begin{array}{l}\text { M3 } \\
M(S D)\end{array}$ & $F$ & $\mathrm{Eta}^{2}$ & Power \\
\hline HAD anxiety & $8.00(3.01)^{a, b}$ & $5.93(1.94)^{a}$ & $6.79(1.90)^{b}$ & 9.33 & 0.41 & 0.96 \\
\hline HAD depression & $12.66(2.38)^{a}$ & $13.59(1.88)^{a}$ & $13.31(2.47)$ & 4.20 & 0.24 & 0.67 \\
\hline CD-RISC & $67.88(8.19)^{a, b}$ & $72.44(7.82)^{a}$ & $72.84(8.55)^{b}$ & 6.64 & 0.37 & 0.87 \\
\hline SWLS & $26.48(5.38)^{a}$ & $28.34(3.95)^{a}$ & $28.31(3.94)$ & 5.72 & 0.29 & 0.82 \\
\hline PPS & $30.24(8.89)$ & $27.10(7.87)$ & $27.55(8.27)$ & 3.10 & 0.19 & 0.55 \\
\hline PSS & $24.73(7.99)$ & $20.09(6.61)$ & $20.82(5.74)$ & 2.93 & 0.39 & 0.43 \\
\hline
\end{tabular}

a-b Significant difference means based on Bonferroni posthoc tests. (Significance level 5\%, two-tailed tests)

M1 - Measurement 1, pre-intervention

M2 - Measurement 2, post-intervention

M3 - Measurement 3, one-year follow up 
Table 8 Comparisons between assessments M1-M3 of Brief COPE interventions

\begin{tabular}{|c|c|c|c|c|c|c|}
\hline $\begin{array}{l}\text { Brief } \\
\text { COPE Dimension }\end{array}$ & $\begin{array}{l}\mathrm{M} 1 \\
\mathrm{M}(\mathrm{SD}) \\
\end{array}$ & $\begin{array}{l}\text { M2 } \\
M(S D) \\
\end{array}$ & $\begin{array}{l}\mathrm{M3} \\
\mathrm{M}(\mathrm{SD})\end{array}$ & $\mathrm{F}$ & $\mathrm{Eta}^{2}$ & Power \\
\hline Self-distraction & $5.86(1.51) \mathrm{a}, \mathrm{b}$ & $4.59(1.43)^{a}$ & $5.00(1.49)^{b}$ & 13.54 & 0.50 & 1.00 \\
\hline Active coping & $6.61(0.83)$ & $6.79(0.88)$ & $6.89(0.92)$ & 1.24 & 0.09 & 0.25 \\
\hline Denial & $3.00(1.24)$ & $2.74(0.90)$ & $2.93(0.96)$ & 0.99 & 0.07 & 0.20 \\
\hline Use of emotional support & $6.38(1.40)$ & $6.55(1.12)$ & $6.79(0.90)$ & 1.79 & 0.12 & 0.34 \\
\hline Behavioral disengagement & $3.24(1.09)$ & $3.07(1.13)$ & $2.93(0.84)$ & 1.53 & 0.10 & 0.30 \\
\hline Substance use & $2.14(0.52)$ & $2.07(0.26)$ & $2.10(0.41)$ & 0.36 & 0.03 & 0.10 \\
\hline Venting & $5.45(1.33)$ & $5.38(1.21)$ & $5.48(1.09)$ & 0.10 & 0.01 & 0.06 \\
\hline Use of instrumental support & $5.93(1.33)$ & $6.28(1.16)$ & $6.41(1.09)$ & 3.21 & 0.19 & 0.56 \\
\hline Positive reframing & $6.28(1.13)$ & $6.31(1.04)$ & $6.52(1.09)$ & 0.72 & 0.05 & 0.16 \\
\hline Self-blame & $5.79(1.42)$ a,b & $4.79(1.42)^{\mathrm{a}}$ & $4.90(1.66)^{b}$ & 13.55 & 0.50 & 1.00 \\
\hline Planning & $6.04(0.92)^{a}$ & $6.57(0.79)^{a}$ & $6.50(1.35)$ & 6.87 & 0.35 & 0.89 \\
\hline Humor & $5.38(1.64)$ & $5.34(1.80)$ & $5.24(1.64)$ & 0.23 & 0.02 & 0.08 \\
\hline Acceptance & $6.50(0.69)$ & $6.57(0.92)$ & $6.64(1.13)$ & 0.35 & 0.03 & 0.10 \\
\hline Religion & $2.76(1.33)$ & $2.97(1.40)$ & 3.07 (1.41) & 2.45 & 0.15 & 0.45 \\
\hline
\end{tabular}

a-b Significant difference means based on Bonferroni post-hoc tests. (Significance level 5\%, two-tailed tests)

M1 - Measurement 1, pre intervention

M2 - Measurement 2, post intervention

M3 - Measurement 3, one-year follow up

"I feel that I can handle the stress in a different way, can in some way have control over it and stop stressing for example by prioritizing certain things and accepting that I cannot do everything." (Participant 16)

Most of the participants describe how, through a changed attitude, they have been influenced in their way of thinking and relate to the degree of control and influence one has in different situations. The participants expressed this through the question of what is possible to influence and what lies outside of control. This question contributed to the participants experiencing that they could relate differently than before to both large and small issues in life. This was seen, for example, in the view on how both study and work tasks should be handled and prioritized for several participants.

\section{To know-how}

The participants describe new behaviors they feel they have learned by participating in the intervention. Relatively many participants describe how they developed new concrete ways to relate to stress and problematic situations based on the theoretical models treated in the intervention. In everyday situations, participants describe that they apply ways that work.

"I am much quicker to separate thoughts, feelings, and actions and know that one does not have to influence the other. However, I still work with it " (Participant 9)
In the one-year follow-up, several participants describe how the theoretical content of the intervention contributed to developing an understanding of stress and stress responses, which served as support and help in everyday life. Overall, data show that the participants were affected by participating in the intervention in several different ways. They expressed themselves as being calmer and better at sorting and prioritizing things according to importance and urgency. A developed ability to reflect and improve skills in stress management together with extended theoretical knowledge is described as underlying this perceived change.

\section{Discussion}

Our study aimed to assess the feasibility of a newly developed stress management intervention, with the overarching feasibility question expressed by Orsmond and Cohn [17], "Can it work?". We investigated this overarching question based on data from three domains with relevance for this question and the present study shows that the intervention is feasible in a nurse education context.

First, we investigated questions relating to recruitment capability. Our analysis revealed that of the almost 400 students, who were offered to participate in the intervention, $29 \%$ chose to participate and about $17 \%$ completed it. The most important reasons for not participating in the stress management intervention were not related to a lack of interest but were primarily due to a focus on their regular studies. Hobbies, family, and long distances to the university were other reasons that non-participant 
students gave when we investigated this. These factors thus constitute perceived barriers. Hammer, Grigsby [34], Hall [35], Yarbrough, Haas [36] as well as other researchers have pointed to the problem of role conflicts and the role overload that causes stress for nursing students as a result of perceived mental stress from both study, leisure and family relationships. Based on our findings, we show that this is an important relationship to address when interventions are planned within nursing education. It seems indeed essential to facilitate participation for the students by taking into account, for example, how ordinary schedules are planned so collisions or conflicts do not occur between different interests competing for the students' time. It should be easy to choose to participate, and synchronization between regular activities and the stress management intervention creates the conditions for participation. Further, other studies discuss the problem with perceived stigma for students who seeks help with mental health issues, as well as for academic problems in the student population [37]. Stress management strategies can therefore be important for reducing mental health problems, given the part stress play in the development of more severe mental health issues [38]. We also know from research that students with the largest needs of help are the least help-seeking [39]. One possible way of reducing potential stigma for participating in interventions like the one described in this article could be to make them part of an institutions'core curriculum, as suggested by [12].

Secondly, we addressed the domain of intervention acceptability. Most of the participants who took part in the intervention had high attendance. Of 73 participants, 43 (about $11 \%$ of 400 ) voluntarily participated in nine or ten sessions. This is particularly interesting considering the general problems in attendance within nursing education when parts are not mandatory [40].

Considering homework adherence, one central aspect of CBT, we found that a majority did not explicitly express that they did this part of the intervention regularly. This is an interesting finding given their expressed high overall satisfaction with the intervention. There are several possible explanations for this phenomenon. It is possible that the group per se is one important aspect of the results. This is well known from research in group therapy and thus potentially relevant in our setting as well [41].

We measured acceptability with three different measurements: CSQ-8, attendance rates, and adherence. Taken together, these measures showed that participants were satisfied with the intervention. Based on our findings, we find our newly developed intervention feasible in the nurse education setting.

Finally, we examined questions relating to the outcome measurements and the preliminary findings of the intervention. We found positive results regarding the majority of the measurements used for the intervention group. The comparison between the intervention and control group showed differences in anxiety, stress, and active coping. These results were also strengthened by both the qualitative and quantitative one-year follow-up for the intervention group. From our open-ended survey data, it appears that most of the participants were affected in several different ways by participation; they felt calmer and better equipped to face stressful situations. The participants also reported that they developed their existing approaches and strategies for private, study, and work-related areas. Our intervention is based on a theoretical mix of both classic and modern CBT. By blending theoretical views and exercises, the participants were trained to become more aware of the interplay between thoughts, feelings, and behaviors, thus gaining tools and insights that could help them both analyze and guide behavior.

However, it is possible that there are reasons to use instruments with greater sensitivity. In a previous study, we used a self-developed instrument to measure stress management competence, which needs to be evaluated psychometrically. This study also reviewed General Selfefficacy with the instrument General Self-efficacy Scale (GSE) as well as Self-esteem with the instrument Rosenberg Self-Esteem Scale (RSES). These instruments showed sensitivity to the intervention in question (self reference). Given the focus of the intervention, there are further possible psychological changes that would be relevant to examine. This applies primarily to psychological flexibility, a measurement not initially identified as crucial, but might be worth to consider for future studies.

There is extensive research on stress and stressrelated problems among students in higher education in general and regarding nursing education globally. However, there is much less research on various interventions aimed at investigating this problem, and to the best of our knowledge, this will be the first study to look at the feasibility of delivering and evaluating a CBT-based stress management training intervention for nursing students. It is also, to our knowledge, the first study to examine the reasons not to participate in a stress management intervention. This is a research contribution taking into consideration the magnitude of the global stress-related problems, such as mental health issues and learning difficulties related to stress. Our findings could be of relevance to researchers, nurse educators as well as educators in a broader sense given that stress-related problems are not limited to nursing education, but concern higher education and those who work there in general [42]. 


\section{Challenges to address in future studies}

Our study also demonstrates that there are challenges to consider when implementing a CBT-based stress management intervention. One such aspect of the implementation that is crucial to consider concerns homework. Homework and skill practice is attributed great importance within CBT because the work of learning new ways of thinking, interpreting, and behaving mainly take place between each session [43]. Even in clinical research, this is an area identified as an Achilles heel [44-46]. Based on our findings, we consider this a significant challenge to address in future studies. The primary responsibility for this challenge lies with the group leader and his/her leadership, and interpersonal approach can be decisive for the outcome [47]. The degree of warmth, openness, and empathy, together with the ability to understand and react to different aspects of group processes has been shown to be important for outcomes. Training in these respects should, therefore, be a key element in the education to lead interventions [41]. Based on our findings with the challenge of addressing the homework effectively, we suggest that in future studies, the facilitators should be working in pairs.

Further, our data showed that for many, long distances to the university were important reasons not to participate in the intervention. An opportunity to face this problem could be to supplement the intervention with a digital counterpart or a hybrid form that would allow more people to participate. Also, participating digitally via internet-based alternatives has the equivalent results for several psychological problem areas [48].

In a wider perspective, it could also be relevant with multi-centered studies and international collaborations, to investigate these problems globally. Longitudinal studies of nursing students as they later take on RN roles, could also add relevant new knowledge to this research area.

\section{Strengths and limitations}

There are several strengths in our study. To the best of our knowledge, few other studies follow up theoretically well-supported ten session interventions using 12 months for a follow-up time. Turner and McCarthy [49] have previously requested studies like this. We have data regarding both barriers to participation and for challenges directly linked to the implementation of the intervention itself. We have specifically examined the participants' perspectives using both quantitative and qualitative data, which gives strength to the results. This is also requested in the literature [26].

However, our study also has some limitations. There are some aspects of the concept of feasibility and acceptability that we have not addressed. Our study focuses mainly on aspects related to recruitment and acceptability. Clinical outcomes fall into the background, and other important aspects such as integration and health economy are left out of the focus of the study, which is a shortcoming in our study. Further, the study design is weak to detect possible effects when evaluating the secondary outcomes and the limited sample should be considered when interpreting our findings. As in many studies, there is a risk of a positive selection bias, where participants that are more interested adhere and provide data, while less interested participants drop out.

\section{Conclusions}

The main purpose of this study was to examine the feasibility of a newly developed stress management intervention for nursing students.

Regarding the first domain, recruitment capability, there were no significant differences in the investigated background variables between the intervention participants and non-participants. Further, approximately $29 \%$ of the students who received the offer to participate choose to do so. The main obstacles expressed by nonparticipants were prioritizing their regular studies.

The second domain concerned intervention acceptability operationalized with the client satisfaction scale, attendance and adherence rates. In summary, the participants' expressed high intervention satisfaction. Based on our findings our study revealed lack of adherence to a specific aspect, homework, of the intervention and recommendation for a dual leadership model were discussed as one way of addressing this problem in future studies.

The third domain investigated regarded outcome measures and an overall preliminary evaluation. Our examination of both quantitative and qualitative data from the participants of the intervention proposed that the intervention, all domains investigated taken together, has the potential of being successful with nursing students. The standardized measures used in our study worked well, but we suggest that future studies measure psychological flexibility, being a more relevant outcome measure for a modern CBT-based intervention.

One can conclude that the intervention may constitute an example of the type of intervention that is requested in the literature by both clinicians and researchers. It has been carried out with relatively simple means, is theoretically well substantiated, easily accessible to the participants, has high acceptability and demonstrated both short-term, but also preliminary, long-term positive results for the participants.

\section{Abbreviations}

CBT: Cognitive behavioral therapy; CD-RISC: The Connor-Davidson resilience scale; CSQ-8: The client satisfaction questionnaire; GSE: General self-efficacy; HAD: Hospital anxiety and depression scale; RCT: Randomized controlled trial 


\section{Supplementary Information}

The online version contains supplementary material available at https://doi. org/10.1186/s12912-021-00761-6.

Additional file 1. Follow-up of the CBT-based stress management project for nursing students.

\section{Acknowledgements}

The authors wish to thank the participants in this study.

\section{Authors' contributions}

UT, BB and FH conceived and designed the analysis. UT collected the data. UT, BB and FH performed the analysis. UT took the lead in writing the manuscript. All authors provided critical feedback and approved the final version of the manuscript.

\section{Funding}

The author(s) received no financial support for the research, authorship and/ or publication of this article. Open Access funding provided by Karlstad University.

\section{Availability of data and materials}

The datasets and analyses for the current study are not publicly available. However, the materials could be available from the corresponding author upon reasonable request.

\section{Declarations}

\section{Ethics approval and consent to participate}

The study was carried out following the ethical guidelines of the latest Helsinki declaration and was approved by the Regional Ethical Board in Uppsala, Sweden (Approval number: 2014/379). Consent was implied by completion of the survey. Individuals who did not desire to participate did not return surveys. The survey cover letter stated these facts and informed participants that their decision to take part in this study was entirely voluntary and that the participants could leave the study at any stage.

\section{Consent for publication}

Not applicable.

\section{Competing interests}

The authors declare that there are no competing interests with respect to the research, authorship, and/or publication of this article.

\section{Author details}

${ }^{1}$ Department of Social and Psychological Studies, Karlstad University, Universitetsgatan 2, 65188 Karlstad, Sweden. ²Department of Nursing, Karlstad University, Universitetsgatan 2, 65188 Karlstad, Sweden.

Received: 1 July 2020 Accepted: 22 November 2021

Published online: 21 January 2022

\section{References}

1. Edwards D, Burnard P, Bennett K, Hebden U. A longitudinal study of stress and self-esteem in student nurses. Nurse Educ Today. 2010;30(1):78-84.

2. Rudman A, Gustavsson JP. Burnout during nursing education predicts lower occupational preparedness and future clinical performance: a longitudinal study. Int J Nurs Stud. 2012;49(8):988-1001.

3. Pulido-Martos M, Augusto-Landa JM, Lopez-Zafra E. Sources of stress in nursing students: a systematic review of quantitative studies. Int Nurs Rev. 2012;59(1):15-25.

4. Gibbons C. Stress, coping and burn-out in nursing students. Int J Nurs Stud. 2010;47(10):1299-309.

5. Hensel D, Laux M. Longitudinal study of stress, self-care, and professional identity among nursing students. Nurse Educ. 2014;39(5):227-31.

6. Öhrstedt $M$, Lindfors P. Linkages between approaches to learning, perceived stress and expected and actual academic outcomes among first-semester psychology students. J Furth High Educ. 2018;42(1):116-29.

7. Robotham D, Julian C. Stress and the higher education student: a critical review of the literature. J Furth High Educ. 2006;30(2):107-17.
8. Blomberg K, Bisholt B, Kullén Engström A, Ohlsson U, Sundler Johansson A, Gustafsson M. Swedish nursing students' experience of stress during clinical practice in relation to clinical setting characteristics and the organisation of the clinical education. J Clin Nurs. 2014;23(15-16):2264-71.

9. Phillips AC, Carroll D, Der G. Negative life events and symptoms of depression and anxiety: stress causation and/or stress generation. Anxiety Stress Coping. 2015;28(4):357-71.

10. Lu H, Barriball KL, Zhang $X$, While AE. Job satisfaction among hospital nurses revisited: a systematic review. Int J Nurs Stud. 2012;49(8):1017-38.

11. Timmins F, Corroon A, Byrne G, Mooney B. The challenge of contemporary nurse education programmes. Perceived stressors of nursing students: mental health and related lifestyle issues. J Psychiatr Ment Health Nurs. 2011;18(9):758-66.

12. Conley CS, Durlak JA, Kirsch AC. A meta-analysis of universal mental health prevention programs for higher education students. Prev Sci. 2015;16(4): 487-507.

13. Regehr C, Glancy D, Pitts A. Interventions to reduce stress in university students: a review and meta-analysis. J Affect Disord. 2013;148(1):1-11.

14. Jones MC, Johnston DW. Reducing distress in first level and student nurses: a review of the applied stress management literature. J Adv Nurs. 2000; 32(1):66-74.

15. Mennin DS, Ellard KK, Fresco DM, Gross JJ. United we stand: emphasizing commonalities across cognitive-behavioral therapies. Behav Ther. 2013;44(2): 234-48.

16. Tickle-Degnen L. Nuts and bolts of conducting feasibility studies. Am J Occup Ther. 2013;67(2):171-6.

17. Terp U, Hjärthag F, Bisholt B. Effects of a cognitive behavioral-based stress management program on stress management competency, self-efficacy and self-esteem experienced by nursing students. Nurse Educ. 2019;44(1): E1-5.

18. Terp U, Bisholt B, Hjärthag F. Not just tools to handle it: a qualitative study of nursing students' experiences from participating in a cognitive behavioral stress management intervention. Health Educ Behav. 2019:1-8.

19. Orsmond Gl, Cohn ES. The distinctive features of a feasibility study: objectives and guiding questions. OTJR. 2015;35(3):169-77.

20. SFS 1992:1434. Högskolelag [The Swedish Higher Education Act]. https:// www.uhr.se/en/start/laws-and-regulations/Laws-and-regulations/TheSwedish-Higher-Education-Act/. Accessed 20 May 2020.

21. SFS 1993:100. Högskoleförordningen [The Swedish Higher Education Ordinance]. https://www.uhr.se/studier-och-antagning/tilltrade-till-hogskola n/Hogskoleforordningen/. Accessed 20 May 2020.

22. Gustavsson P, Jirwe M, Frögéli E, Rudman A. Orsaker till ökande problem med stress under sjuksköterskeutbildningen: En longitudinell analys. Stockholm: Karolinska Institutet; 2014

23. Deary IJ, Watson R, Hogston R. A longitudinal cohort study of burnout and attrition in nursing students. J Adv Nurs. 2003;43(1):71-81.

24. O'Donohue WT, Fisher JE. Cognitive behavior therapy: core principles for practice. Hoboken: Wiley; 2012

25. Kuyken W, Padesky CA, Dudley R. Collaborative case conceptualization: working effectively with clients in cognitive-behavioral therapy. New York: Guilford Press: 2009.

26. Passer MW, Smith RE. Psychology: the science of mind and behavior. 4th ed ed. Boston. London: McGraw-Hill Higher Education; 2009.

27. Kåver A. Att leva ett liv, inte vinna ett krig: Om acceptans. Stockholm: Natur och kultur; 2007

28. Almén N. Stress- och utmattningsproblem: Kognitiva och beteendeterapeutiska metoder. Lund: Studentlitteratur; 2007.

29. Lazarus R, Folkman S. Stress, appraisal, and coping. New York: Springer; 1984

30. Rozental A, Wennersten L. Dansa på deadline: uppskjutandets psykologi. Stockholm: Natur \& kultur; 2014.

31. Neff K. Self-compassion: stop beating yourself up and leave insecurity behind. London: Hodder \& Stoughton; 2011

32. Hayes SC, Strosahl K, Wilson KG. Acceptance and commitment therapy: the process and practice of mindful change. 2nd ed. New York: Guilford Press; 2012. p. xiv, 402

33. Bakker AB, Killmer $\mathrm{CH}$, Siegrist J, Schaufeli WB. Effort-reward imbalance and burnout among nurses. J Adv Nurs. 2000;31(4):884-91.

34. Hayes SC, Strosahl K, Wilson KG. Acceptance and commitment therapy : the process and practice of mindful change. 2nd ed. New York: Guilford Press; 2012. 
35. Kashdan TB, Rottenberg J. Psychological flexibility as a fundamental aspect of health. Clin Psychol Rev. 2010;30(7):865-78.

36. Craig P, Dieppe P, Macintyre S, Michie S, Nazareth I, Petticrew M. Developing and evaluating complex interventions: the new Medical Research Council guidance. BMJ. 2008;337:1-6.

37. Bowen DJ, Kreuter M, Spring B, Cofta-Woerpel L, Linnan L, Weiner D, et al. How we design feasibility studies. Am J Prev Med. 2009;36(5):452-7.

38. Larsen DL, Attkisson CC, Hargreaves WA, Nguyen TD. Assessment of client/ patient satisfaction: development of a general scale. Eval Program Plann. 1979;2(3):197-207

39. Miglietta E, Belessiotis-Richards C, Ruggeri M, Priebe S. Scales for assessing patient satisfaction with mental health care: a systematic review. J Psychiatr Res. 2018;100:33-46.

40. Lally J, Byrne F, McGuire E, McDonald C. Patient satisfaction with psychiatric outpatient care in a university hospital setting. Ir J Psychol Med. 2013;30(4): 271-7.

41. Cohen S, Kamarck T, Mermelstein R. A global measure of perceived stress. J Health Soc Behav. 1983;24(4):385-96.

42. Lee $\mathrm{E}-\mathrm{H}$. Review of the psychometric evidence of the perceived stress scale. Asian Nurs Re. 2012;6(4):121-7.

43. Diener E, Emmons RA, Larsen RJ, Griffin S. The satisfaction with life scale. J Pers Assess. 1985;49(1):71-5.

44. Pavot W, Diener E. Review of the satisfaction with life scale. Psychol Assess. 1993;5(2):164-72.

45. Carver CS. You want to measure coping but your protocol' too long: consider the brief cope. Int J Behav Med. 1997;4(1):92-100.

46. Wong M, Heriot S. Parents of children with cystic fibrosis: how they hope, cope and despair. Child Care Health Dev. 2008;34(3):344-54.

47. Steel P. Arousal, avoidant and decisional procrastinators: do they exist? Personal Individ Differ. 2010;48(8):926-34.

48. Rozental A, Forsell E, Svensson A, Forsström D, Andersson G, Carlbring P. Psychometric evaluation of the Swedish version of the pure procrastination scale, the irrational procrastination scale, and the susceptibility to temptation scale in a clinical population. BMC Psychol. 2014;2(1):54.

49. Zigmond AS, Snaith RP. The hospital anxiety and depression scale. Acta Psychiatr Scand. 1983;67(6):361-70.

50. Lisspers J, Nygren A, Söderman E. Hospital Anxiety and Depression Scale (HAD): some psychometric data for a Swedish sample. Acta Psychiatr Scand. 1997;96(4):281-6.

51. Connor KM, Davidson JR. Development of a new resilience scale: the Connor-Davidson resilience scale (CD-RISC). Depress Anxiety. 2003;18(2):7682

52. Ahern NR, Kiehl EM, Lou Sole M, Byers J. A review of instruments measuring resilience. Issues Compr Pediatr Nurs. 2006:29(2):103-25.

53. Fielding J, Fielding N, Hughes G. Opening up open-ended survey data using qualitative software. Qual Quant. 2013:47(6):3261-76.

54. Braun V, Clarke V. Using thematic analysis in psychology. Qual Res Psychol. 2006:3(2):77-101.

55. Barker C, King N, Snowden M, Ousey K. Study time within pre-registration nurse education: a critical review of the literature. Nurse Educ Today. 2016; 41:17-23.

56. Hammer LB, Grigsby TD, Woods S. The conflicting demands of work, family, and school among students at an urban university. J Psychol. 1998;132(2): 220-6.

57. Hall R. The work-study relationship: experiences of full-time university students undertaking part-time employment. J Educ Work. 2010;23(5):439-49.

58. Yarbrough S, Haas B, Northam S, Duke G, Wieck KL. Role overload theory as a framework for nurse educators to optimize graduate students' learning environment. J Nurs Educ Pract. 2016:6(12):105-12.

59. Michaels PJ, Corrigan PW, Kanodia N, Buchholz B, Abelson S. Mental health priorities: stigma elimination and community advocacy in college settings. J Coll Stud Dev. 2015;56(8):872-5.

60. Stixrud WR. Why stress is such a big deal. J Manag Educ. 2012;36(2):135-42.

61. Gorczynski $P$, Sims-Schouten W, Hill D, Wilson JC. Examining mental health literacy, help seeking behaviours, and mental health outcomes in UK university students. J Ment Health Train Educ Pract. 2017;12(2):111-20.

62. Bati AH, Mandiracioglu A, Orgun F, Govsa F. Why do students miss lectures? A study of lecture attendance amongst students of health science. Nurse Educ Today. 2013:33(6):596-601.
63. Martin Kivlighan D, Adams MC, Obrecht A, Kim JYC, Ward B, Latino CA. Group therapy trainees' social learning and interpersonal awareness: the role of cohesion in training groups. J Spec Group Work. 2019;44(1):62-76.

64. Sharp J, Theiler S. A review of psychological distress among university students: pervasiveness, implications and potential points of intervention. Int J Adv Couns. 2018:40(3):193-212.

65. Helbig S, Fehm L. Problems with homework in CBT: rare exception or rather frequent? Behav Cogn Psychother. 2004;32(3):291-301.

66. Kazantzis N, Brownfield NR, Mosely L, Usatoff AS, Flighty AJ. Homework in cognitive behavioral therapy: a systematic review of adherence assessment in anxiety and depression (2011-2016). Psychiatr Clin N Am. 2017;40(4):62539.

67. Kazantzis N, Whittington C, Zelencich L, Kyrios M, Norton PJ, Hofmann SG. Quantity and quality of homework compliance: a meta-analysis of relations with outcome in cognitive behavior therapy. Behav Ther. 2016:47(5):755-72.

68. Burlingame GM, MacKenzie K, Strauss B. Small group treatment: evidence for effectiveness and mechanisms of change. In: Lambert MJ, editor. Bergin \& Garfield's handbook of psychotherapy and behavior change. 5th ed. Hoboken: Wiley; 2004. p. 647-96.

69. Andersson G. Internet-delivered psychological treatments. Annu Rev Clin Psychol. 2016;12:157-79.

70. Turner K, McCarthy VL. Stress and anxiety among nursing students: a review of intervention strategies in literature between 2009 and 2015. Nurse Educ Pract. 2017:22:21-9.

\section{Publisher's Note}

Springer Nature remains neutral with regard to jurisdictional claims in published maps and institutional affiliations.

Ready to submit your research? Choose BMC and benefit from:

- fast, convenient online submission

- thorough peer review by experienced researchers in your field

- rapid publication on acceptance

- support for research data, including large and complex data types

- gold Open Access which fosters wider collaboration and increased citations

- maximum visibility for your research: over $100 \mathrm{M}$ website views per year

At $\mathrm{BMC}$, research is always in progress.

Learn more biomedcentral.com/submissions 